\title{
UJI AKTIVITAS ANTIPLATELET EKSTRAK DAUN \\ LEMPENI (Ardisia humilis Vahl) PADA MENCIT
}

\author{
(ANTIPLATELET ACTIVITY ASSAY OF LEMPENI LEAF EXTRACT \\ (Ardisia humilis Vahl) ON MICE)
}

PUGUH SANTOSO*

\author{
*Akademi Farmasi Saraswati Denpasar, Jalan Kamboja no. 11A, Denpasar, Bali
}

\begin{abstract}
Abstrak: Daun lempeni telah diteliti memiliki efek memperpanjang waktu pendarahan. Adanya kesamaan aktivitas antara ekstrak daun lempeni dan asetosal memungkinkan adanya potensiasi aktivitas yang ditandai dengan waktu pendarahan yang semakin panjang. Tujuan penelitian ini adalah untuk mengetahui aktivitas ekstrak daun lempeni sebagai antiplatelet. Penelitian merupakan penelitian eksperimental murni dengan rancangan penelitian pre test-post test control group design. Subjek terdiri dari 4 kelompok mencit yang tiap kelompok terdiri dari 5 mencit. Kelompok 1 diberi asetosal dengan dosis $30 \mathrm{mg} / \mathrm{kg}$ bb, kelompok 2 diberi ekstrak daun lempeni dengan dosis $100 \mathrm{mg} / \mathrm{kg}$ bb, kelompok 3 diberi ekstrak daun lempeni dengan dosis 200 $\mathrm{mg} / \mathrm{kg}$ bb dan kelompok 4 diberi ekstrak daun lempeni dengan dosis $300 \mathrm{mg} / \mathrm{kg}$ bb. Waktu pendarahan ditetapkan dengan metode tail bleeding. Hasil menunjukkan bahwa keempat kelompok mengalami perpanjangan waktu pendarahan sebelum dan sesudah perlakuan. Analisis data dilakukan dengan uji Paired Sample T-test dan One Way Anova. Uji Paired Sample T-test menunjukkan perbedaan waktu pendarahan (sig $\mathrm{F}=0,000$ ) yang signifikan antara sebelum dan sesudah perlakuan. Analisis data One Way Anova menunjukkan rerata yang berbeda secara bermakna waktu pendarahan pada keempat kelompok setelah diberikan perlakuan. Penelitian ini menyimpulkan bahwa ekstrak daun lempeni memiliki aktivitas antiplatelet.
\end{abstract}

Kata kunci: Pendarahan, asetosal, ekstrak daun lempeni.

Abstract: Lempeni leaf had been investigated having the effect of extending the bleeding time. The similarity between the activity of lempeni leaf extracts and asetosal allow for potentiating activity characterized by increasingly longer bleeding time. The purpose of this study was to determine the activity of lempeni leaf extract as an antiplatelet. Research is a purely experimental research with pre test-post test control group design. Subjects consisted of 4 groups of mice each group consisted of 5 mice. Group 1 was given asetosal at a dose of $30 \mathrm{mg} / \mathrm{kg}$ bw, group 2 was given lempeni leaf extract at a dose of $100 \mathrm{mg} / \mathrm{kg}$ bw, group 3 was given lempeni leaf extract at a dose of $200 \mathrm{mg} / \mathrm{kg}$ bw and group 4 was given lempeni leaf extract at a dose of 300 $\mathrm{mg} / \mathrm{kg}$ bw. Bleeding time determined by the method of tail bleeding. The results showed that all four groups had longer time of bleeding before and after treatment. Data analysis was performed by Paired Sample T-test and One Way Anova. Paired Sample T-test showed significant differences in bleeding time (sig F $=0.000$ ) between before and after treatment. One Way ANOVA analysis of the data showed a significantly different mean bleeding time in all four groups after being given treatment. This study concluded that the leaf extract lempeni have antiplatelet activity.

Keywords: bleeding, asetosal, lempeni leaf extract.

\section{PENDAHULUAN}

Tromboemboli merupakan salah satu penyebab penyakit dan kematian yang banyak terjadi. Kelainan ini sering merupakan penyulit atau menyertai penyakit lain misalnya gagal jantung, diabetes melitus, varises vena dan kerusakan arteri. Faktor-faktor yang mempengaruhi timbulnya tromboemboli misalnya trauma, kebiasaan merokok, pembedahan, imobilisasi, kehamilan atau akibat obat-obat yang mengandung estrogen. Obat yang digunakan untuk pencegahan dan pengobatan tromboemboli ialah golongan antikoagulan, antitrombosit, dan trombolitik (Gunawan SG dkk, 2012).

Penggumpalan darah sebagai akibat dari agregasi trombosit akan terjadi bila misalnya darah mengalir melalui suatu permukaan yang kasar,

\footnotetext{
* Penulis korespondensi, Hp. 081338644867

e-mail: farmazi.sp@gmail.com.
} 
seperti dinding pembuluh yang kasar, seperti dinding pembuluh yang rusak atau meradang. Zatzat ini, yang singkatnya juga disebut penghambat trombosit ("platelet inhibitor"), berkhasiat menghindarkan terbentuk dan berkembangnya trombi dengan jalan menghambat penggumpalannya (Tjay TH dan Rahadja K, 2013).

Salah satu obat yang banyak digunakan sebagai antiplatelet adalah aspirin atau asetosal dengan efek terbukti pada prevensi trombosis arteri. Asetosal dalam dosis rendah berkhasiat merintangi penggumpalan trombosit. Sejak akhir tahun 1980an, asetosal mulai banyak digunakan untuk prevensi sekunder dari infark otak dan jantung. Resikonya diturunkan dan jumlah kematian karena infark kedua dikurangi sampai 25\% (Tjay TH dan Rahadja K, 2013).

Salah satu tanaman yang tergolong langka adalah tanaman lempeni. Tanaman lempeni merupakan tanaman perdu pohon atau pohon rendah yang tumbuhnya relatif cepat dan mudah dalam pemeliharaan. Daun lempeni yang telah diteliti mengandung triterpena yaitu a-amyrin dan P-amyrin yang berkhasiat sebagai antiplatelet (Aragao et al., 2007; Ching et al., 2010; Medeiros et al.,2002 dalam Jianhong Ching, 2011).

Adanya kesamaan aktivitas antara ekstrak daun lempeni dan asetosal memungkinkan adanya potensiasi aktivitas yang ditandai dengan waktu pendarahan yang semakin panjang maka penulis tertarik untuk melakukan penelitian tentang "Uji Aktivitas Antiplatelet Ekstrak Daun Lempeni (Ardisia humilis Vahl) Pada Mencit”.

\section{BAHAN DAN METODE}

Bahan. Bahan utama untuk penelitian ini adalah daun lempeni (daun berwarna hijau tua) yang hidup di dataran rendah dan diperoleh dari daerah Denpasar. Daun lempeni tersebut dipetik pada pagi hari dengan kondisi cuaca cerah. Bahan kedua adalah hewan percobaan. Hewan coba yang digunakan dalam penelitian ini adalah mencit jantan galur murni berumur 2-3 bulan, berat badan $\pm 21-35$ gram, sehat dan aktif. Jumlah sampel yang digunakan berdasarkan WHO minimal 5 ekor per kelompok yang diambil secara acak/randomisasi. Sampel dibagi dalam 4 kelompok yaitu 4 kelompok perlakuan dengan jumlah sampel 5 ekor tiap kelompok sehingga jumlah yang dibutuhkan adalah 20 ekor (Rachim M, 2012). Bahan lain yang digunakan dalam penelitian ini adalah asetosal, kertas saring, metanol 70\%, alkohol swab, kertas perkamen, es batu, silica gel, makanan mencit, aluminium foil dan plastik wrapping.
Alat. Alat yang digunakan dalam penelitian ini adalah timbangan analitik, blender, gelas kimia, elma sonic, vaccum, labu erlenmeyer, rotary evaporator, desikator, oven, waterbath, spuit sonde, pisau No. 15 Esculap, spidol, sarung tangan, stop watch, masker, corong Bunchner, batang pengaduk dan labu vakum.

Dosis. Dosis yang tersedia adalah dosis pada manusia sehingga perlu dikonversi menjadi dosis mencit. Faktor konversi untuk mengubah dosis dalam $\mathrm{mg} / \mathrm{kg}$ menjadi $\mathrm{mg} / \mathrm{m}^{2}$ dapat dilihat pada Tabel 1.

\section{Tabel 1}

Faktor Konversi Untuk Mengubah Dosis Dalam mg/ kg Menjadi mg/m2 (Hong dkk., 2010 dalam Astuti K.W, 2011)

\begin{tabular}{|c|c|}
\hline Model & Faktor Konversi \\
\hline Mencit & 3 \\
Tikus & 6 \\
Monyet & 12 \\
Anjing & 20 \\
Manusia & 37 \\
\hline
\end{tabular}

Dosis asetosal untuk antitrombosis pada manusia adalah 81-325 $\mathrm{mg}$ per hari Perhitungan dosis asetosal $30 \mathrm{mg} / \mathrm{kg}$ bb (Anderson, 2001 dalam Astuti K.W, 2011).

Dalam penelitian ini dosis ekstrak daun lempeni menggunakan dosis coba- coba. Hal ini dikarenakan belum terdapat sediaan ekstrak daun lempeni di pasaran jadi tidak dapat dipastikan dosis ekstrak daun lempeni yang dapat digunakan sebagai antiplatelet.

Perhitungan dosis ekstrak daun lempeni 100 $\mathrm{mg} / \mathrm{kg}$ bb, yaitu:

Diketahui: Rata-rata berat badan mencit $=30$ gram Ditanya: ? = Jumlah ekstrak daun lempeni yang diambil untuk 1 mencit

Jawab: dosis ekstrak daun lempeni $100 \mathrm{mg} / \mathrm{kg}$ bb

$100 \mathrm{mg}=1 \mathrm{~kg}$ berat badan

$$
\begin{aligned}
& ?=1 \mathrm{~kg} \text { berat badan } \\
& ?=30 \text { gram }=0,03 \mathrm{~kg} \\
& ?=\frac{0,03 \mathrm{~kg}}{1 \mathrm{~kg}} \times 100 \mathrm{mg}=3 \mathrm{mg}
\end{aligned}
$$

Perhitungan dosis ekstrak daun lempeni 200 $\mathrm{mg} / \mathrm{kg}$ bb, yaitu:

Diketahui: Rata-rata berat badan mencit $=31$ gram Ditanya: ? = Jumlah ekstrak daun lempeni yang diambil untuk 1 mencit

Jawab: dosis ekstrak daun lempeni $200 \mathrm{mg} / \mathrm{kg}$ bb

$200 \mathrm{mg}=1 \mathrm{~kg}$ berat badan

$$
\begin{aligned}
& ?=1 \mathrm{~kg} \text { berat badan } \\
& ?=31 \text { gram }=0,031 \mathrm{~kg} \\
& ?=\frac{0,031 \mathrm{~kg}}{1 \mathrm{~kg}} \times 200 \mathrm{mg}=6,2 \mathrm{mg}
\end{aligned}
$$


Perhitungan dosis ekstrak daun lempeni 300 $\mathrm{mg} / \mathrm{kg}$ bb, yaitu :

Diketahui: Rata-rata berat badan mencit $=25$ gram Ditanya: ? = Jumlah ekstrak daun lempeni yang diambil untuk 1 mencit

Jawab: dosis ekstrak daun lempeni $300 \mathrm{mg} / \mathrm{kg}$ bb

$300 \mathrm{mg}=1 \mathrm{~kg}$ berat badan

$$
\begin{aligned}
& ?=1 \mathrm{~kg} \text { berat badan } \\
& ?=25 \text { gram }=0,025 \mathrm{~kg} \\
& ?=\frac{0,025 \mathrm{~kg}}{1 \mathrm{~kg}} \times 300 \mathrm{mg}=7,5 \mathrm{mg}
\end{aligned}
$$

Metode. Metode yang digunakan untuk melakukan analisis data pada penelitian ini adalah Paired Sample T Test dan ANOVA (Analysis of Variance).

\section{HASIL DAN PEMBAHASAN}

Pembuatan Simplisia, Ekstrak Kering dan Penyiapan Hewan Coba. Dalam proses pembuatan simplisia digunakan daun lempeni segar yang kemudian dirajang dan dikering-anginkan hingga diperoleh simplisia daun lempeni sebanyak 100 gram. Sebanyak 100 gram simplisia kemudian dimaserasi dengan menggunakan maserasi ultra sonic sebanyak 3 kali yang dilakukan maserasi I dengan perbandingan simplisia dan pelarut yaitu 1:7,5 dan selanjutnya maserasi II dan maserasi III dengan perbandingan simplisia dan pelarut yaitu 1:4. Ekstrak yang dihasilkan diuapkan dengan menggunakan rotary evaporator. Ekstrak kemudian dipekatkan dengan menggunakan oven dan waterbath. Ekstrak yang dihasilkan disaring dengan vakum dan dikeringkan dengan desikator sehingga diperoleh ekstrak kering sebanyak 768 mg.

Penelitian ini adalah penelitian eksperimental murni dengan menggunakan 20 ekor mencit sebagai sampel obyek perlakuan. Perlakuan tersebut dibagi menjadi 4 kelompok perlakuan yang masing-masing kelompok terdiri dari 5 ekor mencit.
Aktivitas Asetosal Pada Kelompok I (Kelompok Asetosal). Untuk mengetahui aktivitas asetosal, peneliti memberikan perlakuan terhadap kelompok I atau kelompok asetosal. Mencit diberikan perlukaan dan dihitung waktu pendarahan sebelum dan sesudah perlakuan. Perlakuan yang diberikan adalah dengan memberikan asetosal secara oral kepada mencit sebanyak $30 \mathrm{mg} / \mathrm{kg}$ BB. Perlakuan tersebut diberikan sekali sehari selama 7 hari.

Tabel 2

Hasil Perhitungan Waktu Pendarahan Pada Kelompok Asetosal

\begin{tabular}{|c|c|c|}
\hline $\begin{array}{c}\text { Sebelum } \\
\text { (Detik) }\end{array}$ & $\begin{array}{c}\text { Sesudah } \\
\text { (Detik) }\end{array}$ & $\begin{array}{c}\text { Sebelum - } \\
\text { Sesudah (Detik) }\end{array}$ \\
\hline 97 & 187 & 90 \\
\hline 114 & 199 & 85 \\
\hline 104 & 190 & 86 \\
\hline 95 & 185 & 90 \\
\hline 95 & 185 & 90 \\
\hline Mean $=101$ & Mean $=$ & Mean $=88,2$ \\
\hline
\end{tabular}

Tabel tersebut di atas menunjukkan bahwa nilai rata-rata (mean) waktu pendarahan sebelum pemberian Asetosal pada kelompok I adalah 101 detik, rata- rata waktu pendarahan sesudah pemberian Asetosal adalah 189,2 detik sedangkan rata-rata beda waktu pendarahan sebelum dan sesudah pemberian Asetosal adalah 88,2 detik. Hal ini menunjukkan bahwa terdapat peningkatan waktu pendarahan antara sebelum perlakuan dengan sesudah perlakuan. Namun peningkatan tersebut masih harus diuji menggunakan uji statistik berupa $t$ paired (uji beda) untuk mengetahui perbedaan waktu pendarahan secara signifikan.

Tabel 3

Rerata Waktu Pendarahan Sebelum dan Sesudah Pemberian Asetosal

\begin{tabular}{|c|c|c|c|c|}
\hline & Mean & N & $\begin{array}{c}\text { Std. } \\
\text { Deviation }\end{array}$ & $\begin{array}{c}\text { Std. Error } \\
\text { Mean }\end{array}$ \\
\hline $\begin{array}{c}\text { Pair 1 } \\
\text { sebelum }\end{array}$ & 101.00 & 5 & 8.155 & 3.647 \\
sesudah & 189.20 & 5 & 5.848 & 2.615 \\
\hline
\end{tabular}

Tabel 4 Rerata Beda Waktu Pendarahan Sebelum dan Sesudah Pemberian Asetosal

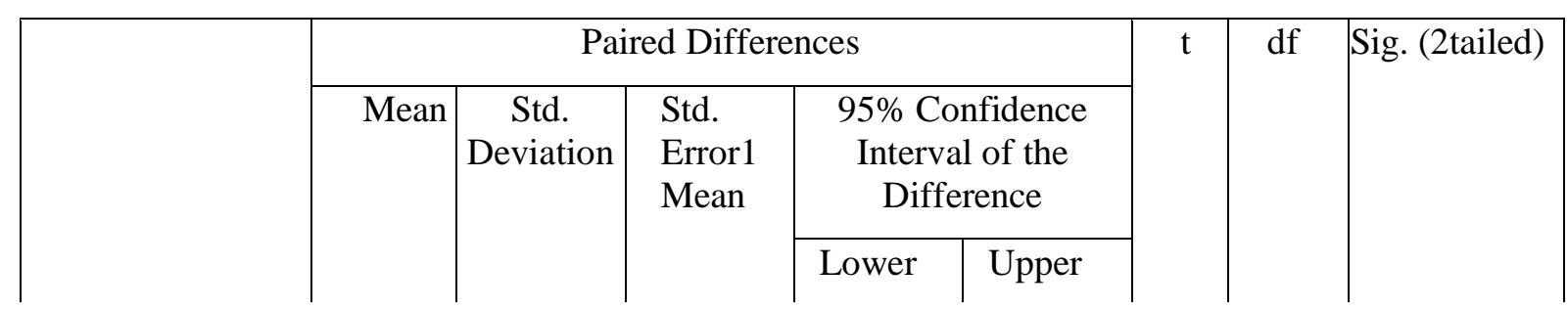




\begin{tabular}{|l|r|r|r|r|r|r|r|r|}
\hline $\begin{array}{l}\text { Pair sebelum - 1 } \\
\text { sesudah }\end{array}$ & 88.20 & 2.490 & 1.114 & -91.292 & -85.108 & 79.20 & 4 & .000 \\
& 0 & & & & & 6 & & \\
\hline
\end{tabular}

Berdasarkan tabel tersebut di atas, dapat dijelaskan bahwa terdapat perbedaan nilai mean dan standar deviasi waktu pendarahan antara sebelum dan sesudah pemberian asetosal. Pada analisis SPSS diperoleh nilai sig $\mathrm{F}=0,00$ pada aras keberatian 5\% (2 arah/2- tailed). Sig F < 0,05; maka Ho ditolak dan Ha diterima. Dapat disimpulkan bahwa terdapat perbedaan waktu pendarahan yang signifikan antara sebelum dan sesudah pemberian asetosal pada mencit yaitu rata- rata waktu pendarahan sebelum pemberian asetosal adalah 101 detik dan rata-rata waktu pendarahan sesudah pemberian asetosal adalah 189,2 detik.

Tromboemboli merupakan salah satu penyebab penyakit dan kematian yang merupakan penyerta penyakit lain misalnya gagal jantung, diabetes melitus, varises vena dan kerusakan arteri. Dalam penelitian ini digunakan tanaman lempeni. Pada beberapa penelitian yang telah dilakukan diketahui bahwa daun lempeni mengandung triterpena yaitu a-amyrin dan P-amyrin yang berkhasiat sebagai antiplatelet (Aragao et al., 2007; Ching et al., 2010; Medeiros et al.,2002 dalam jianhong C, 2011).

Dalam penelitian ini, daun lempeni yang digunakan adalah daun berwarna hijau tua yang hidup di dataran rendah dan diperoleh di Denpasar. Daun lempeni tersebut dipetik pada pagi hari dengan kondisi cuaca cerah yang bertujuan untuk mencegah kualitas simplisia daun yang rendah atau rusak. Daun lempeni selanjutnya disortasi basah untuk memisahkan cemaran dan kotoran dari simplisia yang baru dipetik. Setelah disortasi basah selanjutnya daun lempeni dicuci dengan menggunakan air bersih untuk menghilangkan kotoran dan mengurangi mikroba yang terdapat pada daun lempeni. Daun lempeni yang telah dicuci lalu dirajang, hal ini bertujuan untuk mempermudah dalam proses pengeringan. Daun lempeni yang telah dirajang lalu kering-anginkan dan tidak di bawah sinar matahari langsung. Hal ini bertujuan untuk mengurangi pengaruh sinar UV yang dapat merusak senyawa aktif. Proses pengeringan bertujuan untuk mengurangi kadar air dalam sampel sehingga sampel menjadi lebih awet dan dapat dibuat menjadi ekstrak dan mencegah tumbuhnya kapang. Daun lempeni yang telah dikering-anginkan selama 1 minggu selanjutnya dilakukan sortasi kering yang bertujuan untuk memisahkan bagian yang tidak diinginkan atau ada cemaran. Daun lempeni yang telah disortasi kering selanjutnya diblender untuk mempermudah dalam pembuatan ekstrak. Simplisia daun lempeni disimpan pada toples tertutup untuk mencegah masuknya cemaran dan mennjaga kualitas dari simplisia.

Dalam proses pembuatan ekstrak digunakan pelarut metanol. Pelarut metanol dipilih karena merupakan pelarut yang baik untuk melarutkan aamyrin dan P-amyrin. Konsentrasi dari metanol yang dipilih adalah $70 \%$. Hal ini bertujuan untuk mencegah efek toksik yang dapat ditimbulkan oleh metanol pada saat perlakuan pada hewan coba. Proses ekstraksi yang digunakan adalah proses maserasi dengan menggunakan elma sonic yang bertujuan untuk mendapat hasil yang lebih baik dan waktu yang lebih singkat. Maserasi dilakukan berulang sebanyak 3 kali dengan tujuan untuk memperoleh hasil ekstraksi yang maksimal dan menghindari adanya zat aktif yang belum terekstraksi pada maserasi pertama. Maserat yang diperoleh lalu disaring menggunakan vakum untuk memisahkan residu dengan filtratnya kemudian dipekatkan dengan rotary evaporator yang dibantu dengan oven dan waterbath sehingga diperoleh ekstrak kental. Selanjutnya di vakum untuk menyaring ekstrak dengan pelarutnya yang masih tersisa dan dikeringkan dengan menggunakan desikator. Hal ini bertujuan untuk menghilangkan pelarut yang masih tersisa sehingga dapat menghindari efek toksik yang dapat ditimbukan pada saat pemberian pada mencit dan ekstrak kering juga bertujuan untuk mempermudah dalam pemberian secara oral dan penyimpanannya dapat bertahan lebih lama.

Pada penelitian ini dipilih 20 mencit jantan berumur 2-3 bulan dengan berat badan 21-35 gram yang memiliki kondisi fisik yang sehat dan aktif. Mencit dipilih sebagai hewan coba karena ukuran badannya yang kecil, harga dan biaya perawatannya murah. Mencit diadaptasi selama 1 bulan yang 
bertujuan untuk penyesuaian suhu dan lingkungan pada mencit. Mencit dibagi secara acak menjadi 4 kelompok yang masing-masing kelompok terdiri dari 5 ekor mencit. Setiap mencit diberi makanan berupa pelet dan kwaci dan minuman berupa air putih setiap hari secara ad libitum. Sebelum diberi perlakuan, semua mencit diuji waktu pendarahan (hari ke-0). Hal ini bertujuan untuk membandingkan lama pendarahan sebelum perlakuan dan sesudah perlakuan. Mencit yang telah diukur waktu pendarahan normalnya selanjutnya diberi makanan dan minuman dan mencit mendapatkan perlakuan sesuai dengan kelompoknya masing-masing. Asetosal dengan dosis $30 \mathrm{mg} / \mathrm{kg}$ bb dan ekstrak kering daun lempeni dengan dosis $100 \mathrm{mg} / \mathrm{kg} \mathrm{bb}$, $200 \mathrm{mg} / \mathrm{kg}$ bb dan $300 \mathrm{mg} / \mathrm{kg}$ bb kemudian diencerkan dengan air dan diberikan per oral kepada hewan percobaan yaitu mencit selama 7 hari. Sampel diberikan per oral menggunakan sonde. Dipilih rute per oral karena asetosal dan ekstrak daun lempeni lazim digunakan per oral. Pada hari ke-7 dilakukan uji waktu pendarahan pada mencit yang bertujuan untuk mengukur lama pendarahan setelah pemberian asetosal dengan dosis $30 \mathrm{mg} / \mathrm{kg}$ bb dan ekstrak daun lempeni dengan dosis yang berbeda yaitu $100 \mathrm{mg} / \mathrm{kg}$ bb, $200 \mathrm{mg} / \mathrm{kg}$ bb dan 300 $\mathrm{mg} / \mathrm{kg} \mathrm{bb}$.

Pada pengujian ini yang diamati yaitu waktu perdarahan sebelum dan sesudah pemberian. Waktu perdarahan diamati untuk melihat pengaruh bahan uji terhadap pembentukan sumbat hemostatik sementara yaitu hemostatik fase platelet. Waktu dari mulai terjadinya luka sampai terbentuknya sumbat hemostatik sementara pada daerah luka disebut waktu perdarahan. Adanya efek ditunjukkan oleh waktu perdarahan yang semakin panjang setelah pemberian bahan uji.

Metode analisis data yang digunakan dalam penelitian ini adalah paired sampel t tes dan Anova. Metode analisis data Paired sampel t tes digunakan untuk membandingkan dua sampel yang berpasangan (Najmah, 2011). Dalam penelitian ini paired sampel $t$ tes digunakan untuk membandingkan lama pendarahan pada hari ke-0 dan ke-7 pada kelompok asetosal dan ekstrak daun lempeni. Metode analisis data Anova (Analysis of varians) digunakan untuk pengujian lebih dari dua kategori pada variabel independen (Najmah, 2011). Dalam penelitian ini Anova digunakan untuk membandingkan lama pendarahan pada keempat kelompok perlakuan yaitu kelompok asetosal, kelompok ekstrak daun lempeni dengan dosis 100 $\mathrm{mg} / \mathrm{kg} \mathrm{bb}$, ekstrak daun lempeni dengan dosis 200 $\mathrm{mg} / \mathrm{kg}$ bb dan ekstrak daun lempeni dengan dosis $300 \mathrm{mg} / \mathrm{kg}$ bb.

Hasil penelitian menunjukkan bahwa kelompok 1 yang menerima asetosal $30 \mathrm{mg} / \mathrm{kg}$ bb mengalami perpanjangan waktu perdarahan dari 101 detik menjadi detik. Kelompok 2 yang menerima ekstrak daun lempeni $100 \mathrm{mg} / \mathrm{kg}$ bb mengalami perpanjangan waktu perdarahan dari 111 detik menjadi 212,4 detik. Kelompok 3 yang menerima ekstrak daun lempeni $200 \mathrm{mg} / \mathrm{kg}$ bb mengalami perpanjangan waktu perdarahan dari 122,8 detik menjadi 231,6 detik. Kelompok 4 yang menerima ekstrak daun lempeni $300 \mathrm{mg} / \mathrm{kg}$ bb mengalami perpanjangan waktu perdarahan dari 83,8 detik menjadi 242,2 detik. Analisis data juga dilakukan dengan uji One Way Anova dan menunjukkan rerata yang berbeda secara bermakna pada waktu perdarahan sig anova $=0,000(\operatorname{sig}<0,05)$ pada keempat kelompok sesudah diberikan perlakuan yang dapat disimpulkan bahwa terdapat perbedaan waktu pendarahan pada kelompok asetosal, kelompok ekstrak daun lempeni dengan dosis $100 \mathrm{mg} / \mathrm{kg}$ bb, ekstrak daun lempeni dengan dosis $200 \mathrm{mg} / \mathrm{kg}$ bb dan ekstrak daun lempeni dengan dosis $300 \mathrm{mg} / \mathrm{kg}$ bb. Perpanjangan waktu pendarahan pada kelompok ekstrak daun lempeni diduga disebabkan kandungan a-amyrin dan Pamyrin yang terdapat pada ekstrak daun lempeni.

\section{SIMPULAN}

Dari hasil pengolahan uji coba Ekstrak daun Lempeni serta pengeolahan data, ditemukan hasil bahwasanya Ekstrak Daun Lempeni memiliki aktivitas antiplatelet.

\section{DAFTAR PUSTAKA}

Astuti K.W, 2011, Kombinasi Asetosal Dan Ekstrak Buah Mengkudu (Morinda CitrifoliaL.) Dapat Memperpanjang Waktu Perdarahan Dan Koagulasi Pada Mencit (online) (http://www.pps.unud.ac.id/thesis/pdf_thesis/un ud-363-185934947 tesis_s2_ketut_widyani.pdf diakses tanggal 9 januari 2014)

Backer, TC. A. and R. C. Bakhuizen Van Den Brink. 1968. Flora of Java II, III. WoltersNoordhorff N.V.-Groninger-The Netherlans

Deniek G. Sukarya (Ed.), 2013, 3500 Plants Species of The Botanic Gardens of Indonesia. PT Sukarya \& Sukarya Pandetama. Indonesia

Gunawan SG, Nafriadi RS dan Elysabeth, 2012, Farmakologi dan Terapi, Edisi 5, Balai Penerbit FKUI, Jakarta 804-813

Harborne JB, 1987, diterjemahkan oleh Kosasih dkk, Metode Fitokimia Penuntun Cara Modern Menganalisis Tumbuhan, Edisi 2, ITB Bandung, Bandung 6-7 
Heyne K, 1987, Tumbuhan Berguna Indonesia, Edisi 3, Badan Penelitian dan Pengembangan Kehutanan Departemen Kehutanan, Jakarta, 1556

Jianhong C, 2011, Chemical And Pharmacological Studies Of Ardisia Elliptica: Antiplatelet, Anticoagulant Activities And Multivariate Data Analysis For Drug Discovery, Tesis dipublikasikan, Singapura, Department Of Pharmacy National University of Singapore, (online) http://scholarbank.nus.edu.sg/bitstream/handl e/10635/30563/ChingJH.pdf? sequence $=1$ diakses tanggal 16 januari 2014)

Labadie R.P, 2003, Prosea Plant Resources OfSouthEast Asia12(3)Medicinal And Poisonous Plants 3, Edisi 3, Backhuya Publisher, Netherland, 80

Lawrence, G.H.M. 1964. Taxonomy of Vascular Plants. The Macmilan Company: New York

Najmah, 2011, Managemen dan Analisa Data Kesehatan Kombinasi Teori dan Aplikasi SPSS, Nuha Medika, Yogyakarta, 126,134

Rachim M, 2012, Pengaruh Pemberian Jus Mengkudu (Morinda Citrifolia L) Dengan Pemberian Dosis Bertingkat Terhadap Jumlah Trombosit,(online),(Universitas

Diponegoro, (http://eprints.undip.ac.id/37576/1/Marisa_Rach im, G2A008110, LAP K TI.pdf diakses tanggal 16 januari 2014)

Sari Denni Kartika, Wardhani Dyah Hesti, Prasetyaningrum Aji, 2012, Pengujian Kandungan Total Fenol Kappahycus Alvarezzi
Dengan Metode Ekstraksi Ultrasonik Dengan Variasi Suhu Dan Waktu, (online),(http://publikasiilmiah.unwahas.ac.id/in dex.php/PROSIDING_SN

ST_FT/article/view/19 diakses tanggal 16 januari 2014)

Sanusi Ibrahim, Marham Sitorus, 2013 Teknik Laboratorium Kimia Organik, Graha Ilmu:Yogyakarta, 16,48,64,66

Suastri AN, 2013, Perbandingan Efektifitas Aspirin, Melon dan Kombinasi Asetosaldan Buah Melon Sebagai Antikoagulan, Karya Tulis Ilmiah tidak dipublikasikan, Denpasar, Akademi Farmasi Saraswati Denpasar

Syamsudin, Darmono, 2011, Farmakologi Eksperimental, Universitas Indonesia:Jakarta, 37

Sweetman SC, Blake PS, Brayfield Alison, Mcglashan JM, Neathercoat GC, ParsonsAV, Cadart Catherine RM, Eager Kathleen, Handy Susan

L, Hashmi Fauziah T, Ho Sue W, Humm Joanna A, Macpherson Jean, Siew Mellisa TA, Sutton Sandra, Viedge Gerda W, Hatwal

Chloe SAJ, King Elizabeth D, O'Reilly James, Shute Elen R, Iskandar Christine L, Evans Michael C, 2009, Martindale, Edisi 36, London:RPS Publishing, 20-24

Tjay TH dan Rahadja K, 2013, Obat-Obat Penting, Edisi 6, Jakarta: PT. Elex Media Computindo, 614-617 